Doi: HTTPS://DOI.ORG/10.23910/IJBSM/2017.8.2.1800j

\title{
Forest Resource Use Patterns in a Protected Forest Reserve in Western Zimbabwe-the Case of Fuller Protected Forest
}

\author{
J. Mudekwe* \\ Dept. of Forest and Wood Science, Faculty of AgriSciences, University of Stellenbosch, \\ Private Bag X01 Matieland (76 02), South Africa
}

\section{Corresponding Author}

J. Mudekwe

e-mail: jmudekwe@yahoo.com

\author{
Article History \\ Manuscript No. AR1800j \\ Received in $27^{\text {th }}$ February, 2017 \\ Received in revised form $26^{\text {th }}$ March, 2017 \\ Accepted in final form $7^{\text {th }}$ April, 2017
}

\begin{abstract}
Communal households in Zimbabwe are no different to other areas of the developing world when it comes to harvesting natural forest resources. A range of forest resources is harvested from protected forests and woodlands for direct home consumption and for sale. In Zimbabwe only a few studies have attempted to describe and characterise the dynamics of forest product use by communities living adjacent to protected forests. This study was conducted in the Baikiaea plurijuga forests in Fuller Forest, western Zimbabwe, protected since 1943. The study explored the characteristics and dynamics of forest resource use by communities surrounding this protected forest. Results indicated that all households, rich and poor, were harvesting at least some forest resources from the protected forest. The most frequently harvested resources being firewood, wood for curios, thatch grass, wild fruits, timber for construction and fencing and those who owned livestock used the forest for livestock grazing. The extraction and use of 23 different products was recorded across five villages. The top five harvested forest products in terms of the mean proportion of households using them were fuelwood, building poles, thatch grass, wild fruits and broom grass. Forest products were harvested both for own consumption and for sale.
\end{abstract}

Keywords: Forest products, protected forest, use patterns, livelihoods

\section{Introduction}

In western Zimbabwe the protected forests cover 800000 ha and a significant proportion of the communal area population in the region live adjacent to these protected forests. The Baikiaea plurijuga forests and woodlands form the most extensive vegetation types in these areas. General observation suggests that in the communal areas products derived from the protected forests perform a crucial role in meeting basic needs, contributing to livelihood security and in providing a safety net for rural households in times of crisis. Commercialisation of products from these protected forests is increasing as more rural households seek additional means for cash income.

Protected forests have traditionally been valued as a source of commercial timber and wildlife. All other products, no matter their importance to rural people have been classified as "minor forest products or non-timber forest products (NTFP)" (Posey, 1982; Falconer, 1990; Denevan, 1992; Bradley and Dewees, 1993; Clarke et al., 1996). Non-timber forest products (NTFPs) have been harvested by rural populations for subsistence use and trade over thousands of years and still represent an important source of income to millions of people worldwide. Over the past two decades, NTFPs obtained from plant resources have gained much attention in conservation circles. The growing commercial trade of natural products, in particular plant medicines and crafts, has resulted in the harvest of increasing volumes from wild plant populations (Rebelo and Holmes, 1988; Cunningham, 1993; Clay, 1997; Kuipers, 1997; Tiwari, 2000; Ticktin, 2004).

Research in southern Africa has shown that most rural households depend on harvesting of a wide range of forest products for both household consumption and for sale (see for example McGregor, 1995; Clarke et al., 1996; Campbell et al., 1997; Shackleton et al., 1999). Forest resources play a key role in rural economies and household production systems (Judge, 1975; Campbell, 1987; Campbell et al., 1991; McGregor, 1991; Burger, 1993). Forest products and services contribute to food security and the basic well-being of rural households and are particularly significant among poor households in rural areas (Cavendish, 1996; Campbell et al., 1997). Communities in communal areas sometimes depend heavily on forests and forest products at various times of the year, and are vulnerable 
to reduced supply or access to these products (Clarke et al., 1996; Brigham et al., 1996). Many of the rural livelihood strategies linked to forest are pursued in combination with agricultural activities such as crop and livestock production (Vermeulen, 1993). Forests also provide a reserve of products upon which people can fall back for subsistence and income in times of hardships, for example crop failure or unemployment (Arnold, 1998). Where farming is marginal and where the high probability of crop failure has an influence on the survival of rural households, survival through forest products exploitation becomes an important factor (Clarke et al., 1996). For some households forest-based income generating activities can be a major income source (Arnold, 1998).

For rural people living adjacent to protected forests, the forests are viewed either as no go areas depending on protection measures put in place by the forestry authorities or as sources of subsistence goods that can be harvested illegally in a confrontational situation with the forestry authorities. Under the confrontational situation the adjacent rural people use the protected forests without regard of the future. In most situations the use practices are destructive for example, harvesting and collection of all ripe and mature fruits, digging out thatch grass swards instead of cutting the stems just above the ground surface, setting forest fires to flash wildlife, complete debarking of selected tree species for medicines and clearing the forests for agricultural purposes.

As pressures on protected forests increase, forest managers, policymakers and planners need a clear picture of those dependent on the forests, wholly or partially, and of the specific goods and services that the forests provide. This approach is a step towards a better understanding of the contributions that forests make to peoples' livelihoods and a better understanding of how protected forests can be managed for sustainable resource use as well as for protecting the species, processes and values of the resource base.

The controlled harvesting of forest products by local communities has been widely proposed as a strategy to stem the rate of deforestation and forest degradation while enhancing local livelihoods (Nepstad and Schwartzman, 1992). This 'good forest use' approach has spawned much research on the role of forest products to livelihood systems and in forest conservation (Peters, 1996). Despite growing concern over the destruction of commonly harvested forest products, as well as their potential to foster forest conservation, information on the local use patterns of protected forests is available only in disparate case studies. Few studies in Zimbabwe (Vermeuelen, 1993; Forestry Commission, 1994; Cunliffe, 2000) have investigated the patterns and characteristics of use of protected forests by local people.

The objective of this study was to determine the overall use patterns of forest products by rural communities living around a protected forest reserve and to suggest strategies for sustainable resource use to meet the needs of future generations. The driving key questions were "What is the dimension of forest products utilisation in the protected forest i.e. types of products extracted and used, purposes of harvesting, when do people harvested/collect forest products, who are involved in harvesting/collecting, where are the products collected from in the forest and what mechanisms could be put in place for the sustainable use management of the resources by the adjacent rural people and the forestry authority"

\section{Materials and Methods}

\subsection{Study Area}

Fuller Forest Reserve lies between Latitude $18^{\circ} 08^{\prime}$ to $18^{\circ} 35^{\prime}$ South and longitude $25^{\circ} 15^{\prime}$ to $25^{\circ} 56^{\prime}$ East. The forest reserve covers 23300 ha. It is managed by the Zimbabwe Forestry Commission on behalf of the state. The forest borders with Hwange Communal Area in the north and commercial game ranches in the south. The Bulawayo to Victoria Falls road and the Bulawayo to Victoria Falls railway line run along the northern and southern boundaries of the forest respectively. The Victoria Falls International Airport is located in the northwestern part of the forest reserve. The world-renowned resort town of Victoria Falls and the Hwange National Park are $25 \mathrm{~km}$ and $120 \mathrm{~km}$ away from Fuller Forest respectively.

The dominant climatic characteristic in and around Fuller Forest is a short and erratic rainfall season from midNovember to mid-March. The dry season ranges from April/ May to October/November. The annual average rainfall for the forest is about $550 \mathrm{~mm}$ (Forestry Commission, 1992). The long-term (45 years) annual average rainfall for Victoria Falls, $25 \mathrm{~km}$ from Fuller Forest is about $600 \mathrm{~mm}$ (Anderson et al., 1993). There is considerable year-to-year variation in the total amount of rainfall received annually. The mean annual temperature in the study area is approximately $21.5^{\circ} \mathrm{C}$. Mean monthly temperatures in the hot and cold months are about $30^{\circ} \mathrm{C}$ and $17^{\circ} \mathrm{C}$ respectively (Nyamapfene, 1991).

The Kalahari Sands cover the bulk of Fuller Forest and the surrounding area. The sands comprise deep unconsolidated Tertiary Sands of Aeolian origin (Nyamapfene, 1991). The Kalahari Sands are strongly uniform physically and chemically (Nyamapfene, 1991). The soils comprise well drained and deep, medium grained sands (Anderson et al., 1993). The extremely low occurrence of silt and clay particles $(<10 \%)$ is due to the absence of any weatherable minerals (Lockett, 1979). The sands are inherently of extreme low fertility (Nyamapfene, 1991). The high permeability and low fertility severely limits the potential of these soils for crop production.

The vegetation of the Kalahari Sands has been described by Fanshawe and Savory (1964), Huckabay (1986), Wood (1986) and Childes and Walker (1987). The Kalahari Sands ridge in Fuller Forest supports a predominantly Baikiaea plurijuga 
forest type. The vegetation shows a distinct catenary pattern with Baikiaea on the ridge and Burkea, Terminalia, Combretum mixed scrub and occasionally Colophospermum mopane in seasonally water logged depressions. Baikiaea is an African genus, with five other species confined to the tropical lowland rain forests of west-central Africa, the Guinea-Congolian floral region (Huckabay, 1986). The Baikiaea plurijuga forest formation in its present range in central southern Africa (Figure 1) [Insert Figure of Ba forest formations] is believed to be at its environmental and climatic limits (Brummitt, 1986; Huckabay, 1986). The Baikiaea plurijuga forest formation is uniquely restricted to Kalahari Sands, under an annual rainfall regime ranging from about $1000 \mathrm{~mm}$ in southeast Angola to about $500 \mathrm{~mm}$ in northwest Zimbabwe (Huckabay, 1986; Wood, 1986).

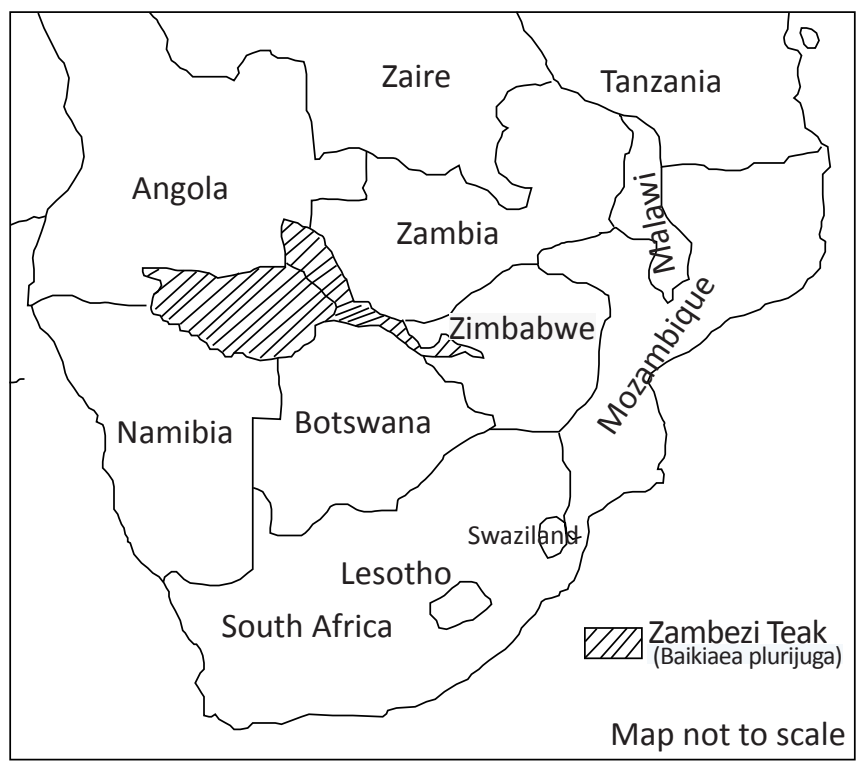

Figure 1: Baikiaea plurijuga (Ba) formations in Central Africa

\subsection{Methods}

The study was conducted in five villages that were randomly selected from twelve villages that surround the forest. Participatory Rural Appraisal (PRA) methods were used to determine the dynamics of local use of forest products. It was carried out in two ways. Firstly, group discussions were held in the form of village participatory workshops so as to understand the general historical profiles of the villages, types of forest products collected from the forest, harvesters' preferences, gender or age of those harvesting the products and what the products were used for in the homes. Secondly, key informant interviews were conducted with selected individuals and groups (Chambers, 1992, 1994 a,b, 1997; Kumar 1993). A house-to-house survey was not carried out since it was considered that the desired information would be obtained using these two methods. The methods were used with modification where necessary as dictated by local situation e.g., levels of literacy. Individuals who attended the PRA meetings were those who heeded their traditional leadership calls for the meetings and did so at their own will.

The purpose of the PRA methods above were

(i) Historical profile discussions - to find out the communities' knowledge of the history of settlement in the area

(ii) Forest products use analysis - to find out the types of products harvested from Fuller Forest, who harvested them, what they were harvested for, peoples' preferences of the products, and the species' preferences for different products.

(iii) Seasonal calendars-to get some impressions of seasonality of use of forest products by users.

At each of the five sample villages participants indicated in plenary the products and services they extracted and/or used from Fuller Forest. A list of these products and services was written on flip charts in the local language (SiNdebele), which is spoken by the majority of the people in the study area. The individual products and services were written on separate cards for use in the user group discussions.

At each sample village one group was tasked to work on the resource use patterns, in five steps.

(i) The first step involved discussions of first settlements in and around the forest, followed by creating a list of products collected from the forest.

(ii) The second step involved scoring out of 100 , the relative importance of each resource to women and men. The group collected the cards bearing names of the products and services from the forester and randomly arranged them in a column on the ground. Counters e.g., a 100 small pebbles or tree seeds were used for scoring the importance of each resource to women and men. Importance of a resource was defined as its usefulness or relative contribution to a household livelihood. The most important resource to either gender received the highest scoring by placing the highest number of counters beside that resource. The least number of counters were placed against the least important resource.

(iii) In step three, assuming there were 100 households in a village, group participants were asked to score the proportion of households using each of these products as a percentage of the total number of households. The two hands were a tool that was used for estimating the percentages, where ten fingers represented $100 \%, 9$ fingers $90 \%$; 8 fingers $80 \%$ and 1 finger $10 \%$ of the total households.

(iv) In step four, the two hands tool and the process as above was also used to score the proportion of each resource collected for own use and for sale as a percentage.

(v) In step five, seasonal calendar, group participants were asked to indicate when each mentioned resource was harvested or collected during the year.

Results of the group work were presented in plenary. Plenary discussions served the purpose of giving the workshop 
representatives the chance to reflect on the findings of the other groups.

\section{Results and Discussion}

\subsection{Social histories of Fuller Forest and the surrounding area}

Historical accounts of Fuller Forest and its immediate surrounding communal area revealed eight distinct historical phases i.e., (i) the initial settlements around Fuller Forest, (ii) the arrival of the Forestry Commission and the Rhodesia Native Timber Concession, (iii) the arrival of relocated households from other districts, (iv) evictions of households from the gazetted forest, (v) introduction of some wildlife species and the subsequent hunting safaris, (vi) the advent of indigenous African Foresters, (vii) the establishment of the Forest Protection Unit, and (viii) the land redistribution programme.

The local Tonga and Nambya ethnic groups displayed extensive knowledge of the history of Fuller Forest and the surrounding areas. They were the oldest ethnic residents of the area around Fuller Forest. These ethnic groups are concentrated in Monde and Chidobe villages. Three and two elderly PRA workshop participants from Monde and Chidobe sample villages respectively reported their first encounter with Forestry Commission was when they were employed as patrolmen in the early 1940s. Another early event they remembered was the timber logging concession by the Rhodesia Native Timber Concession, popularly known as RNTC locally. The Forestry Commission and the concessionaire prohibited local people from cutting commercial timber species such as Baikiaea plurijuga, Pterocarpus angolensis, Guibourtia coleosperma and Afzelia quanzensis. Hunting of any wildlife was also prohibited. Some forest managers allowed locals to graze their cattle in the forest and collecting forest products while others strictly prohibited the activities. A Mr Sparrow, a forester at Fuller between the 1960s and 1970s was reported to have been particularly good to locals as he was a Friend of the Chief and was not very strict when people grazed their cattle in the forest.

Three elderly men aged about 63 years from Monde sample village remembered that European Foresters marked the boundaries of Fuller Forest in the early 1930s. The Forestry Commission's records indicate that the forest was gazetted as a protected state forest in 1936 . They further added that households that were resident within the boundaries of the protected forest were evicted between 1968 and 1970.

To quote one Tonga elderly man with respect to the demarcation of the forest and the subsequent application of forest legislation:

"It was clear to us that the forest was no longer ours. The Forestry Commission considered us abusers of the forest and poachers. How can we be called poachers, yet it is the Forestry Commission that encroached onto our ancestral land?"
Asked why locals could not simply respect the forestry laws and regulations as required, villagers displayed ignorance of the provisions of these laws and regulations. Contrary some villagers were aware that people could get permits from the forest offices every Thursday. One woman from $\mathrm{BH} 28$ Village said,

"Maybe people are simply reluctant to get permits because the forest offices are very far away and there are dangerous wild animals in the forest such as buffalos"

The curio carvers' user group discussions substantiated the restricted access to commercial timber species. The group suggested that they should be considered for timber concessions for their trade as well. To the question why they do not tender for such concessions when the opportunities arise some individuals indicated that they were usually not aware when the tenders were advertised yet others said they would not be able to meet the tender requirements let alone afford the timber royalty fees. Interviews with the Chief Conservator of Forests confirmed that tenders for timber concessions were regularly advertised in the print media including local publications and notices were usually posted at the local forest office.

Interviews with a sample of livestock owners revealed that they were aware of grazing leases operating in other protected forests yet such an opportunity did not exist in Fuller Forest. Contacted for comments, the Chief Conservator and the local Forester indicated that on several occasions arrangements had been made with locals to graze their livestock in the forest at certain times of the year. More often than not such arrangements were discontinued when livestock owners abused the agreed system. According to this discussion group the desire was for people to graze cattle in the forest throughout the year. Asked about the apparent conflicts amongst forest users despite the Fuller management plan, the forester pointed out that the plan was rarely put in practice.

In all five sample villages elderly men reported that the early timber concessions and Forestry Commission's fire protection activities provided employment opportunities to locals. Young males at meetings in these villages disputed the fact citing that the opportunity no longer existed for locals but for relatives of forest and safari camp managers who were imported from outside the district even for manual jobs.

\subsection{Importance of different products harvested}

Fuller Forest is an important source of a wide range of essential subsistence goods and services for the local villagers. Residents of the five villages extract and use a wide range of 23 different forest products that is relatively similar across the five villages (Table 1). However, the proportion of households harvesting any type of forest product varied across the sampled villages (Table 1). The mean proportion of households extracting and using forest products across the five villages indicated that firewood was the most widely 


\begin{tabular}{|c|c|c|c|c|c|c|c|}
\hline \multirow[t]{2}{*}{ Forest product } & \multicolumn{5}{|c|}{ Village } & \multirow[t]{2}{*}{ Mean } & \multirow[t]{2}{*}{ Top 10 ranking products } \\
\hline & BH 11 & Chidobe & $\mathrm{BH} 28$ & Chikandakubi & Monde & & \\
\hline Firewood & 100 & 100 & 100 & 80 & 80 & 92 & 1 \\
\hline Construction poles & 100 & 100 & 90 & 60 & 70 & 84 & 2 \\
\hline Thatch grass & 100 & 0 & 80 & 90 & 60 & 66 & 3 \\
\hline Fruits & 100 & 100 & 50 & 40 & 20 & 62 & 4 \\
\hline Broom grass & 100 & 0 & 80 & 60 & 50 & 58 & 5 \\
\hline Grazing & 0 & 0 & 70 & 75 & 80 & 45 & 6 \\
\hline Wood for implements & 100 & 0 & 70 & 50 & 0 & 44 & 7 \\
\hline Caterpillars & 80 & 50 & 40 & 0 & 15 & 37 & 8 \\
\hline Mushrooms & 0 & 100 & 70 & 0 & 15 & 37 & 8 \\
\hline Medicines & 40 & 90 & 10 & 10 & 12 & 32.4 & 9 \\
\hline Fencing branches & 100 & 0 & 40 & 10 & 0 & 30 & 10 \\
\hline Honey & 20 & 10 & 20 & 60 & 20 & 26 & - \\
\hline Timber for carving & 0 & 20 & 0 & 0 & 70 & 18 & - \\
\hline Dyes & 80 & 0 & 0 & 10 & 0 & 18 & - \\
\hline Fibres & 0 & 0 & 0 & 30 & 40 & 14 & - \\
\hline Dagga for bricks & 0 & 0 & 20 & 0 & 10 & 6 & - \\
\hline Wood for furniture & 0 & 10 & 0 & 10 & 0 & 4 & - \\
\hline Pit sand & 0 & 10 & 10 & 0 & 0 & 4 & - \\
\hline Manure for fields & 10 & 0 & 0 & 0 & 0 & 2 & - \\
\hline Wildlife & 0 & 10 & 0 & 0 & 0 & 2 & - \\
\hline Stones for building & 0 & 0 & 10 & 0 & 0 & 2 & - \\
\hline Reeds & 0 & 0 & 0 & 0 & 5 & 1 & - \\
\hline Ilala palm for weaving & 0 & 0 & 0 & 0 & 5 & 1 & - \\
\hline Total & 930 & 590 & 750 & 585 & 552 & & \\
\hline Rank & 1 & 3 & 2 & 4 & 5 & & \\
\hline
\end{tabular}

extracted. The top most products, in order of importance, are firewood, construction poles, thatch grass, wild fruits, broom grass, grazing, and wood for implements, edible caterpillars, mushrooms, medicinal plants, and fencing branches. Less frequently mentioned products across the villages were wildlife, pit sand, clay and building stones, and seedlings from the Forestry Commission nursery.

Villagers were reluctant to talk about wildlife products and, to a lesser extent, the use of products such as honey and commercial timber species used for making cottage furniture and wooden curios. Activities involving the harvesting and use of these products are strongly discouraged and criminalised by the Forestry Commission. These results are comparable to findings of Mudekwe (2002) for Mafungabusi Forest in the Midlands Province, where the top five highly preferred products were firewood, thatch grass, broom grass, wild fruits and grazing for livestock. Cunliffe (2000) recorded that in Gwaai/Bembesi Forests the commonly harvested forest resources were thatch grass, firewood, grazing for livestock, construction poles, wild fruits, honey and medicinal plants.

Fuller Forest played an important role in the supply of construction poles as chronicles from participants indicated that the adjacent communal area had become degraded of good quality poles of the preferred species. Large diameter posts that are durable have become scarce or unavailable in the adjacent communal area due to population growth and the related harvesting pressure. More than $50 \%$ of households in the sample villages lived in pole structures. Large and small livestock pens and field fences were constructed using different sizes of poles. 
Grazing is a valuable resource for livestock owners living adjacent to Fuller Forest. Trees are an essential component of the grazing and browsing (Campbell et al., 1988).

Fuller had several woody plant species that provided edible foods in the form of fruits, seeds, leaves and young shoots. Children mostly consumed wild fruits. Adults also collect fruits when harvesting other forest products or herding livestock in the forest. Some of these wild foods act as emergency foods especially during drought years.

The roots, leaves, seeds and bark of 45 plant species from Fuller Forest are used in the rural health care system as traditional medicine. Plant material combinations were

\begin{tabular}{|c|c|c|c|c|c|c|c|}
\hline \multirow[t]{2}{*}{ Forest product } & \multicolumn{5}{|c|}{ Village } & \multirow[t]{2}{*}{ Mean } & \multirow[t]{2}{*}{ Top 10 ranking products } \\
\hline & $\mathrm{BH} 11$ & Chidobe & $\mathrm{BH} 28$ & Chikandakubi & Monde & & \\
\hline Construction poles & 100 & 95 & 100 & 100 & 100 & 99 & 1 \\
\hline Firewood & 100 & 75 & 100 & 100 & 95 & 94 & 2 \\
\hline Honey & 100 & 15 & 100 & 98 & 85 & 79.5 & 3 \\
\hline Fruits & 70 & 25 & 98 & 98 & 95 & 77.2 & 4 \\
\hline Thatch grass & 100 & 0 & 90 & 85 & 90 & 73 & 5 \\
\hline Broom grass & 60 & 0 & 99 & 98 & 100 & 71.4 & 6 \\
\hline Medicines & 20 & 25 & 90 & 95 & 90 & 64 & 7 \\
\hline Caterpillars & 80 & 50 & 50 & 50 & 85 & 63 & 8 \\
\hline Fencing branches & 100 & 0 & 100 & 100 & 0 & 60 & 9 \\
\hline Grazing & 0 & 0 & 100 & 100 & 100 & 60 & 9 \\
\hline Mushrooms & 0 & 100 & 100 & 0 & 90 & 58 & 10 \\
\hline Wood for implements & 100 & 0 & 95 & 90 & 0 & 57 & \\
\hline Pit sand & 0 & 100 & 100 & 0 & 0 & 40 & - \\
\hline Dagga for bricks & 0 & 0 & 100 & 0 & 100 & 40 & - \\
\hline Fibres & 0 & 0 & 0 & 98 & 95 & 38.6 & - \\
\hline Dyes & 60 & 0 & 0 & 96 & 0 & 31.2 & - \\
\hline Manure for fields & 100 & 0 & 0 & 0 & 0 & 20 & - \\
\hline Wildlife & 0 & 100 & 0 & 0 & 0 & 20 & - \\
\hline Stones for building & 0 & 0 & 100 & 0 & 0 & 20 & - \\
\hline Reeds & 0 & 0 & 0 & 0 & 100 & 20 & - \\
\hline Ilala palm for weaving & 0 & 0 & 0 & 0 & 100 & 20 & - \\
\hline Timber for carving & 0 & 1 & 0 & 0 & 15 & 3.2 & - \\
\hline Wood for furniture & 0 & 2 & 0 & 2 & 0 & 0.8 & - \\
\hline Total & 990 & 587 & 1422 & 1210 & 1340 & & \\
\hline Rank & 4 & 5 & 1 & 3 & 2 & & \\
\hline
\end{tabular}

used for simple and common ailments such as diarrhoea, coughs, headaches, minor wounds, colds, eye infections and backaches. The local people were generally knowledgeable about the plant species that could be used and how to make the preparations. Poverty, exorbitant prices of formal drugs and lack of formal health care facilities in the communal area force people to depend on traditional plant medicines.

Fuller also had several species of wildlife and a variety of insects, caterpillars, birds and rodents that were harvested for food. Records from the Fuller Forest office indicated that many of the animal species were poached by snaring to provide bushmeat. Some parts of the animals (bones, teeth, tails, skins) were reported to be used in the traditional health care system.

\subsection{Subsistence use of forest products}

In the sampled villages most households collected forest products for household consumption rather than for sale (Table 2 and Table 3 ). The top ten products collected 
by households for own use include construction poles, firewood, honey, fruits, thatch grass, broom grass, medicines, caterpillars, fencing branches, grazing and mushrooms (Table 2).

The proportions of households that collected forest products for own use differed across the villages. $\mathrm{BH} 28$ village had the highest proportion of households collecting forest products from Fuller Forest for own use while Chidobe had the lowest. Chidobe village had adjacent woodlands that were still well wooded. The reasons for this situation around Chidobe were not very obvious, but it appeared that the village traditional institutions have been successful in controlling use of natural resources in the village woodlands.

Not all households from the villages collect forest products from Fuller Forest. Villages that still had substantially intact local woodlands had fewer households collecting forest products from Fuller Forest. These were Chidobe and $\mathrm{BH}$
11 villages. More often than not harvesters from these two villages went to Fuller Forest to get highly preferred products not available locally, such as straight poles, species with durable wood and fuelwood of highly preferred species.

\subsection{Commercial use of forest products}

The PRA exercises showed considerable commercialisation of various forest products harvested from Fuller Forest (Table 3 ). The top ten products collected or harvested by households for sale include wood for furniture, wood for curio carving, caterpillars, medicines, fruits, honey, dyes, broom grass, firewood and thatch grass (Table 3 ). There is considerable variation in the proportion of households collecting forest products for sale between villages while there is little variation in the total number of different types of forest products collected for sale between the villages. The highest proportion of households that collected forest products for sale are found in Chidobe village and the least proportion of households that

\begin{tabular}{|c|c|c|c|c|c|c|c|}
\hline \multirow[t]{2}{*}{ Forest product } & \multicolumn{5}{|c|}{ Village } & \multirow[t]{2}{*}{ Mean } & \multirow[t]{2}{*}{ Top 5 rank } \\
\hline & BH 11 & Chidobe & $\mathrm{BH} 28$ & Chikandakubi & Monde & & \\
\hline Wood for furniture & 0 & 98 & 0 & 98 & 0 & 39 & 1 \\
\hline Timber for carving & 0 & 99 & 0 & 0 & 85 & 37 & 2 \\
\hline Caterpillars & 20 & 50 & 50 & 50 & 15 & 37 & 3 \\
\hline Medicines & 80 & 75 & 10 & 5 & 10 & 36 & 4 \\
\hline Fruits & 30 & 75 & 2 & 2 & 55 & 22 & 5 \\
\hline Honey & 0 & 85 & 0 & 50 & 15 & 20 & 6 \\
\hline Dyes & 40 & 0 & 0 & 4 & 0 & 8.8 & 7 \\
\hline Broom grass & 40 & 0 & 1 & 2 & 0 & 8.6 & 8 \\
\hline Firewood & 0 & 25 & 0 & 0 & 5 & 6.0 & 9 \\
\hline Thatch grass & 45 & 65 & 40 & 25 & 80 & 5.0 & 10 \\
\hline Building poles & 0 & 5 & 0 & 0 & 10 & 3.0 & - \\
\hline Wood for implements & 0 & 0 & 5 & 10 & 0 & 3.0 & - \\
\hline Mushrooms & 48 & 25 & 0 & 55 & 75 & 2.0 & - \\
\hline Fibres & 0 & 0 & 0 & 2 & 5 & 1.4 & - \\
\hline Fencing branches & 0 & 0 & 0 & 0 & 0 & 0 & - \\
\hline Manure for fields & 0 & 0 & 0 & 0 & 0 & 0 & - \\
\hline Wildlife & 0 & 0 & 0 & 0 & 0 & 0 & - \\
\hline Pit sand & 0 & 0 & 0 & 0 & 0 & 0 & - \\
\hline Grazing & 0 & 0 & 0 & 0 & 0 & 0 & - \\
\hline Dagga for bricks & 0 & 0 & 0 & 0 & 0 & 0 & - \\
\hline Stones for building & 0 & 0 & 0 & 0 & 0 & 0 & - \\
\hline Reeds & 0 & 0 & 0 & 0 & 0 & 0 & - \\
\hline Ilala & 0 & 0 & 0 & 0 & 0 & 0 & - \\
\hline Total & 303 & 600 & 118 & 273 & 335 & - & - \\
\hline Rank & 2 & 1 & 5 & 4 & 3 & - & - \\
\hline
\end{tabular}


sold some forest products are in $\mathrm{BH} 28$ village. Chidobe village households appear more enterprising. The largest curio stand is found adjacent to this village.

The sale of wooden curios showed increased commercialisation of the woodcraft industry around Fuller Forest. The woodcraft entrepreneurs are mostly family members. There are eleven curio stalls of different sizes along the stretch of the BulawayoVictoria Falls Highway that passes through the northeast of Fuller Forest. Each market stall has a specific organisational set-up, ranging from loosely structured production and marketing units to well organised units with joining fees, committees and various rules of conduct.

The major markets for the woodcraft industry are the international and local tourists using the highway, those embarking or taking off from the Victoria Falls International Airport and those staying in the Victoria Falls resort town. During the focus group discussions it was estimated that a skilled curio carver could generate an annual income in the range of USD 1000 to 1250 using the current official USD currency in Zimbabwe. About $17 \%$ of the households in the study area gain some income from activities related to the woodcraft industry.

Thatch grass collection has seen a tremendous increased commercialisation. The rise is attributed to increased development of thatched safari lodges in the province. Thatch grass harvesting is normally a single person activity that often involves women. When the grass is abundant in the forest after a good rainy season, a single woman can harvest thatch grass with an annual value of USD 350 to 750 .

Some households collected fruits for commercial purposes. The fruits were normally sold by women and children along the roadside or sold to middlemen who in turn sold them in the Victoria Falls town.

For some households these forest-based incomes are often important in filling seasonal or other cash flow gaps and in helping to cope with particular household expenses. For example, woodcraft artefacts can be sold throughout the year but households were found to respond to unusual opportunities like a rise in national and international tourism activities particularly during public holidays and school holidays. During the course of this study an international importer constructed a warehouse near the Victoria Falls International Airport but just outside Fuller Forest for the storage of wooden curios prior to exportation. Local people involved in the curio industry were increasingly using this opportunistic facility for income generation. On average a carver using this facility may earn a gross amount of about US\$1200. However, the process requires good negotiating skills as most of the products are bought at wholesale prices. The importer indicated that the destinations for these curios were Germany and Italy.

The above margins of income represent significant contribution to rural livelihoods particularly for the poor households who can engage in thatch grass harvesting for sale. These values are generally higher than the official minimum wage in formal employment. Shackleton et al., (2000a) note that at such levels of forest derived incomes many poor households would find it impossible to replace these contributions from other sources.

The demand for some of the forest products such as fruits, fuelwood and bushmeat is generally high in urban areas. The high rural-urban migration has meant that most of the urban dwellers have some links with their rural roots in one way or another. Thus, most of the urban dwellers have consumed these products at some point. They can therefore not resist buying them when they are introduced in urban areas (Mangoyana et al., 2003).

While the demand for a number of the forest products is high, the marketing of most of the products is not well structured. The suppliers, in this case those involved in harvesting, are not organised. Furthermore, they are often limited by, among other things, i) high costs of transporting their products over long distances, for example Victoria Falls town is $25 \mathrm{~km}$ from the forest, ii) variation of woodland production from year to year, mainly due to frequent droughts and impacts of wild fires, and iii) the lack of market information. In some cases the selling of the products is opportunistic with harvesters occasionally selling their products by the roadside when one is in dire need of cash (see also Brigham et al., 1996).

This study has shown that forests can be taken as landscapes capable of reducing household vulnerability in that they provide a biomass reserve upon which people can depend on daily or fall back to for subsistence and income in cases of crop failure, unemployment and other kinds of hardships, or to meet exceptional household or individual needs. In their studies Arnold (1998) and Falconer (1990) also demonstrated the contribution of local forest and woodlands to rural peoples' livelihoods. They displayed that products from forests play an important supplementary and/or safety net role. In this study harvesters and users of forest products tend to be agriculturists who still draw on forests for inputs that cannot be produced on the farm.

The technology available to user groups determines the use and commercialisation of specific products, as observed around Fuller Forest. Two examples demonstrate this: i) The low inputs required to acquire tools for the woodcarver business, such as home made axes, adzes and chisels, mean that many people gain entry into the woodcarving activity. However, the quality of products produced would be significantly of low standards and such technology results in considerable waste of the valuable wood and the loss of species preferred in the business. ii) The shift from head loading in firewood harvesting to transportation by scotch cart and vehicles was more apparent with the harvesting of firewood destined for the urban market where quantity of the product was critical for enhanced incomes.

\subsection{Distance from Fuller Forest and use patterns}

Spatial proximity appeared to have a strong bearing on local people's use of forest resources from Fuller Forest. Two villages, $\mathrm{BH} 11$ and Chidobe that share common boundaries with Fuller Forest had higher proportions of households 
harvesting different products from Fuller Forest than other villages further away. A different situation exists with respect to harvesters of thatch grass. Thatch grass harvesters came from villages more than $10 \mathrm{~km}$ away, and some obtained permits that allowed them to camp in the forest for about three weeks harvesting thatch grass. The opportunity to get permits and permission to camp in the forest for extended periods changes the whole pattern of use with regards to distance from the forest. Non-residents from villages afar and not only residents from villages adjacent to Fuller may harvest forest products of their choice.

It appears old traditions of forest use patterns still exist in communities around Fuller Forest. For example, wildlife poachers from near and far away villages and as far away as Hwange and Victoria Falls towns, camp in the forest for extended periods during their hunting and game trapping expeditions. This was a practice common before the forest was gazetted (Plan Afric, 2002). During the cropping season and especially in drought times some cattle herders from villages 10 to $12 \mathrm{~km}$ away from Fuller Forest, camp in the forest where the grazing resource would be in abundance and water would be available from the artificial game watering points. In years when the mopane worm is in abundance, harvesters come from different parts of the province and only leave the forest after processing and packaging the worms. These scenarios greatly expand the spatial bounds of the forest-using community.

Several studies have demonstrated the impact that distance and spatial variation in woodland resource availability have on the pattern of woodland resource use and on the woodland itself (see for example, Wilson, 1989; Fortmann and Nabane, 1992). In Fuller it was observed that the number of tree stumps cut mainly for construction poles increased with proximity to the settled areas. This might be due to the fact that there are fewer costs involved by harvesting near homesteads in terms of time and availability of transport required to move the products from the forest. On the other hand villagers pointed out that good quality construction poles were scarce at the village/forest boundary and people had to travel deeper into the forest to find such material. It was also observed that households further away from the forest maintained fuelwood, bark fibre and thatch grass stocks unlike those nearer the forest who could afford to extract the resources as and when they required them.

\subsection{Gender issues in resource use}

There were differences in resources extracted and used by women and men with regards to importance of the resources and customary allocation of labour between genders. Women generally allocated higher priority than men to thatch grass, broom grass, firewood, medicines, ilala palm leaves for weaving and reeds. In addition, women were the primary harvesters of the greatest range of forest resources. On the other hand men gave higher ratings than women to grazing, building and fencing poles, wood for carving curios, medicines and bark fibre. In their study in the Northern Province and KwaZulu Natal, Shackleton et al., (2000b) showed that women were more involved in forest products gathering and processing than men.

Women were the principal collectors of firewood for domestic uses and were highly selective in the species used. Men do occasionally collect firewood when it is required in large quantities and in large sizes.

Gender differences in harvesting or collection of forest products depend on the partitioning of household roles between genders. Women would normally collect products for immediate household consumption e.g. fruits, broom grass, caterpillars and mushrooms while men catered for products used around the home e.g. construction poles and fuelwood when it was required in large sizes and quantities. In most cases women have an extra role of harvesting thatch grass, but men would have the responsibility of transporting the grass and use it for thatching.

\subsection{Seasonality of forest resource harvesting and use}

The availability and harvesting of forest products in Fuller Forest was found to be seasonal (Table 4), and some explanation of the seasonality is provided in Table 5. Wild fruits may be found both during the dry and wet seasons. Availability of products such as mopane worms, mushrooms and some wild vegetables are linked to the wet season. Grazing in the forest is linked to the wet season as a strategy to keep cattle away from crops in the communal area.

Other products are best harvested during the dry season e.g. construction and fencing poles. This is the time when people are free from farming activities. It is also the time when household members can invest in craftwork, repairs to houses, fences and livestock pens.

There was little variation in the lists of products extracted from Fuller over months of the year between the villages sampled. Firewood was harvested throughout the year in all villages, but this activity peaked before and during the winter season. Timber harvesting for carving continued throughout the year, but in the woodcarving industry activities peaked during schools and public holidays. These were the periods when carvers expected to get high revenues from the increased numbers of tourists to and from Victoria Falls.

The timing of harvesting forest resources is linked to the labour demands (Timmermans, 2000). The dry season (May to October) is the time when household labour is relatively free after agricultural activities. Once crop harvesting is over households commence construction activities of living structures and livestock pens. This is the time when repairs are also done to huts, houses, livestock pens and fences. Opportunistic harvesting or collection also takes place while household members are undertaking other activities such as fetching water, collecting firewood or herding livestock.

In the west of Zimbabwe where the demarcated state forests are found, the amount and distribution of rainfall influences the production of grazing material. Quality and/or abundance of grazing tend to fluctuate with annual rainfall, and is also 


\begin{tabular}{|c|c|c|c|c|c|c|c|c|c|c|c|c|}
\hline Resource & $\mathrm{J}$ & $\mathrm{F}$ & $\mathrm{M}$ & $\mathrm{A}$ & $\mathrm{M}$ & $\mathrm{J}$ & $\mathrm{J}$ & $\mathrm{A}$ & $\mathrm{S}$ & $\mathrm{O}$ & $\mathrm{N}$ & $\mathrm{D}$ \\
\hline $\begin{array}{l}\text { Trusses \& cross } \\
\text { members }\end{array}$ & $\bullet$ & $\bullet$ & $\bullet$ & $\bullet$ & $\bullet$ & $\stackrel{\bullet}{\bullet}$ & $\stackrel{\bullet \bullet \bullet}{\bullet}$ & $\bullet \bullet \bullet$ & $\stackrel{\bullet \bullet}{\bullet}$ & $\bullet \bullet$ & $\bullet$ & $\bullet$ \\
\hline Thatch grass & & & & & & $\begin{array}{l}\bullet \bullet \bullet \\
\bullet \bullet \bullet \bullet\end{array}$ & $\begin{array}{c}\bullet \bullet \bullet \\
\bullet \bullet \bullet \bullet \bullet \bullet\end{array}$ & $\bullet \bullet$ & & & & \\
\hline Broom grass & & & & & & $\begin{array}{l}\bullet \bullet \bullet \\
\bullet \bullet \bullet \bullet\end{array}$ & $\begin{array}{c}\bullet \bullet \bullet \\
\bullet \bullet \bullet \bullet \bullet \bullet\end{array}$ & $\bullet \bullet$ & & & & \\
\hline Construction poles & $\bullet$ & $\bullet$ & $\bullet$ & $\bullet$ & $\bullet \bullet$ & $\bullet \bullet \bullet$ & $\bullet \bullet \bullet$ & $\bullet \bullet \bullet \bullet$ & $\bullet \bullet \bullet$ & $\bullet \bullet \bullet$ & $\bullet \bullet$ & $\bullet \bullet \bullet \bullet$ \\
\hline Reeds & & & & & & $\bullet \bullet$ & $\bullet \bullet$ & $\bullet \bullet$ & & & & \\
\hline Ilala & & & & & & $\bullet \bullet$ & $\bullet \bullet$ & $\bullet \bullet$ & & & & \\
\hline Grazing & $\bullet \bullet \bullet$ & $\bullet \bullet \bullet$ & $\bullet \bullet \bullet$ & $\bullet \bullet$ & & & & & & & & $\bullet \bullet \bullet$ \\
\hline Fire wood & $\bullet$ & $\bullet$ & $\bullet$ & $\bullet$ & $\bullet$ & $\bullet \bullet \bullet$ & $\bullet \bullet \bullet$ & $\bullet \bullet$ & $\bullet$ & $\bullet$ & $\bullet \bullet$ & $\bullet \bullet \bullet$ \\
\hline Mopane worms & & & & & & & & & & & $\bullet$ & $\bullet \bullet \bullet$ \\
\hline Honey & & & & & $\bullet \bullet$ & $\bullet \bullet \bullet$ & $\bullet \bullet \bullet$ & & & & & \\
\hline Wild fruits & $\bullet$ & $\bullet$ & $\bullet$ & $\bullet$ & $\bullet$ & $\bullet$ & $\bullet$ & $\bullet \bullet$ & $\bullet \bullet$ & $\bullet \bullet$ & $\bullet \bullet$ & $\bullet \bullet$ \\
\hline Bark fibre & $\bullet$ & $\bullet$ & $\bullet$ & $\bullet$ & $\bullet$ & $\bullet$ & $\bullet \bullet$ & $\bullet \bullet$ & $\bullet \bullet$ & $\bullet \bullet$ & $\bullet \bullet$ & $\bullet \bullet$ \\
\hline Medicinal plants & $\bullet \bullet$ & $\bullet \bullet$ & $\bullet \bullet$ & $\bullet \bullet$ & $\bullet$ & $\bullet$ & $\bullet$ & $\bullet$ & $\bullet$ & $\bullet$ & $\bullet$ & $\bullet \bullet$ \\
\hline Mushrooms & $\bullet \bullet$ & $\bullet \bullet$ & $\bullet \bullet$ & & & & & & & & & \\
\hline Timber for carving & & & & & $\bullet$ & $\bullet \bullet \bullet$ & $\bullet \bullet \bullet$ & $\bullet \bullet \bullet$ & $\bullet \bullet \bullet$ & $\bullet \bullet$ & $\bullet \bullet$ & $\bullet \bullet$ \\
\hline Honey & & & & $\bullet \bullet$ & $\bullet \bullet$ & $\bullet \bullet$ & & & & & & \\
\hline
\end{tabular}

Table 5: General comments on patterns of seasonality and harvesting activities

\begin{tabular}{|c|c|}
\hline Resource & Comments \\
\hline Trusses \& cross members & Increased construction and repair works during months when there are less agricultural activities. \\
\hline Thatch grass & The product will be mature this period. \\
\hline Broom grass & The product will be mature this period \\
\hline Construction poles & Increased activities of repairs \& new construction works. \\
\hline Reeds & Product will be ready for harvesting. \\
\hline Ilala & Product will be ready for harvesting. \\
\hline Grazing & $\begin{array}{l}\text { Increased use of forest during wet season, when cattle are to be kept away from crop fields. } \\
\text { Strategy of reserving communal area grazing resource for winter. FC encourages cattle removal } \\
\text { at start of hunting season (April to November). }\end{array}$ \\
\hline Fire wood & Harvested throughout the year, with peaks in cold season and public holidays. \\
\hline Mopane worms & Heaviest outbreak experienced in December. \\
\hline Honey & Good yields in cold season. \\
\hline Wild fruits & Availability \& yields variable between wet \& dry season. Harvested mainly by women and children. \\
\hline Bark fibre & $\begin{array}{l}\text { Heavy use during construction time, but need may arise any time. Bark may be stocked for } \\
\text { emergency repairs. }\end{array}$ \\
\hline Medicinal plants & Increased harvesting in wet season, easy to identify plants when in leaf. \\
\hline Mushrooms & $\begin{array}{l}\text { Abundant during the wet season. Yields may be reduced due to fire that consumes growth } \\
\text { substrate. }\end{array}$ \\
\hline Timber for carving & $\begin{array}{l}\text { Activity intensifies pre and during public holidays. Generally, carving takes place all year round. } \\
\text { Numbers of buyers peak in April, August and December so more timber required. }\end{array}$ \\
\hline
\end{tabular}


influenced by tree cover. To take advantage of these factors livestock owners around Fuller made maximum use of the grazing available in the forest during the wet season, a strategy that appeared to save grazing areas in the communal area for use during winte.

There appears to be several factors that determine household use and commercialisation of forest products in Fuller Forest. The legal framework for managing Fuller Forest impinges directly on how the local communities use the forest. The act of alienating the local residents from the forest undermined indigenous respect of the forest as the forest somewhat became irrelevant to them (Mukamuri, 1995). Policies that limit use and commercial extraction of forest products also limit the growth of potentially important forest based enterprises that would otherwise improve the livelihoods of the local people (Dewees, 1994). There is evidence that criminalizing use and commercialisation of forest products can result in the breakdown of judicious use of forests and resultantly sustainability of the forests. Reduced benefits to locals often lead to reduced incentives for caring for the forests (Clarke et al., 1996; Ticktin, 2004). During this study villagers reported that they deliberately poach forest products in retaliation for the harassment they get from forest guards. Household wealth status also seems to have some influence on patterns of forest products use. Changes in a household's income tend to alter its demand or preference for forest products. McGregor (1995) showed that poorer households depend more on the sale of harvested products than the rich. For communities in the west of Zimbabwe, including those around Fuller Forest, cattle ownership is an important social status. As wealth rises, households invest in livestock particularly cattle and as this happens so too will demands for forest-based goods for livestock maintenance such as graze and browse, poles for livestock pens, yokes and skeys. This aspect was quite evident in Fuller Forest during focus group discussions. Livestock owners did not mince their word concerning their need to access the grazing in Fuller Forest on an all-year round basis.।

\subsection{Main species harvested for different products}

The five most frequently mentioned (preferred) firewood species across the sample villages were Combretum collinum, Baikiaea plurijuga, Brachystegia spiciformis, Colophospermum mopane and Burkea africana. These species were preferred for their characteristic hot flames, burning with little smoke and lasting embers.

The most preferred species for construction poles were Burkea africana, Croton gratissimus, Colophospermum mopane, Baikiaea plurijuga, Erythrophleum africanum, Diplorhynchus condylacaporn, Terminalia species and Kirkia acuminata.

The most common woody plant species used for edible foods are shown in Table 6. During this study villagers identified 20

\begin{tabular}{|c|c|}
\hline Species & Part used for food \\
\hline Grewia flavescens & Fruit, eaten fresh or dried \\
\hline Grewia bicolour & Fruit \\
\hline Flacourtia indica & Fruit, eaten fresh \\
\hline Guibourtia coleosperma & Seed, boiled and syrup eaten, roasted and eaten \\
\hline Afzelia quanzensis & Young leaves, eaten fresh \\
\hline Diospyros mespiliformis & Fruit eaten fresh or preserved for latter use \\
\hline Vitex payos and Vitex mombassae & Fruit \\
\hline Vangueria infausta & Fruit, eaten fresh or dried \\
\hline Vangueriopsis lanciflora & Fruit, eaten fresh or dried \\
\hline Schynziophyton rautanennii & Nuts \\
\hline Strychnos cocculoides & Fruit, eaten fresh \\
\hline Adansonia digitata & Fruit/young leaves, eaten fresh \\
\hline Ximenia caffra & Fruit, eaten fresh \\
\hline Ficus sycomorus & Fruit, eaten fresh or dried \\
\hline Friesodielsia obovata & Fruit, eaten fresh \\
\hline Boscia albitrunca & Roots, dried and ground into powder for porridge \\
\hline Bauhinia thonningii & Pods and seeds \\
\hline Xanthocercis zambesiaca & Fruits, eaten fresh or dried and ground into powder that makes porridge \\
\hline Strychnos madagascariensis & Fruit, pulp can be dried and eaten latter \\
\hline Grewia retinervis & Fruit \\
\hline
\end{tabular}


woody species from which people commonly harvested and collected fruits. The most common species used for medicinal purposes are listed in Table 7. Some of the wildlife species

\begin{tabular}{|c|c|}
\hline Species & Part(s) used \\
\hline Afzelia quanzensis & $\begin{array}{l}\text { Roots, infusion claimed to } \\
\text { cure bilharzia }\end{array}$ \\
\hline Bauhinia petersiana & $\begin{array}{l}\text { Leaves boiled and inhaled } \\
\text { for common colds }\end{array}$ \\
\hline Bauhinia thonningii & $\begin{array}{l}\text { Bark crushed to treat minor } \\
\text { woods }\end{array}$ \\
\hline Dialium engleranum & $\begin{array}{l}\text { Leaves when crushed are a } \\
\text { remedy for coughs }\end{array}$ \\
\hline Crossopteryx febrifuga & $\begin{array}{l}\text { Crushed and soaked bark } \\
\text { and leaves used in treat- } \\
\text { ment of fever }\end{array}$ \\
\hline Stereospermum kunthianum & $\begin{array}{l}\text { Chewing the pods relieves } \\
\text { hard coughs }\end{array}$ \\
\hline Markhamia acuminata & $\begin{array}{l}\text { Small roots are slightly } \\
\text { burnt and ground into a } \\
\text { black powder and rubbed } \\
\text { into incised skin to relieve } \\
\text { backache }\end{array}$ \\
\hline Clerodendron glabrum & $\begin{array}{l}\text { Leaves and roots to treat } \\
\text { stomach-aches and snake- } \\
\text { bites respectively }\end{array}$ \\
\hline Diplorhynchus condylocarpon & $\begin{array}{l}\text { Roots to treat diarrhoea \& } \\
\text { leaves for headaches }\end{array}$ \\
\hline $\begin{array}{l}\text { Olea europaea subsp. afri- } \\
\text { cana }\end{array}$ & Fresh bark relieves colic \\
\hline Schrebera trichoclada & Roots used as eye lotion \\
\hline Diospyros mespiliformis & $\begin{array}{l}\text { Small twigs, leaves and bark } \\
\text { for various ailments }\end{array}$ \\
\hline Terminalia sericea & Roots cure diarrhoea \\
\hline Combretum zeyheri & $\begin{array}{l}\text { Roots cure chronic nose } \\
\text { bleeding and haemorrhoids }\end{array}$ \\
\hline Flacourtia indica & Roots, bark \\
\hline Ochna pulchra & Roots as lucky charms \\
\hline Dombeya rotundifolia & $\begin{array}{l}\text { Infusion of bark to induce } \\
\text { labour in women }\end{array}$ \\
\hline Ziziphus mucronata & $\begin{array}{l}\text { Leaves, roots, bark for sev- } \\
\text { eral ailments }\end{array}$ \\
\hline Burkea africana & Roots for treatment of sores \\
\hline
\end{tabular}

are listed in Table 8.

Table 8: Wildlife species found in Fuller Forest

\begin{tabular}{|c|c|}
\hline Species & Main use \\
\hline Elephant & Hunting and photographic safaris \\
\hline Buffalo & $\begin{array}{l}\text { As above but also poached for sub- } \\
\text { sistence }\end{array}$ \\
\hline Lion & Hunting and photographic safaris \\
\hline Leopard & Hunting and photographic safaris \\
\hline Hyena & Hunting and photographic safaris \\
\hline Sable & $\begin{array}{l}\text { Highly preferred for subsistence and } \\
\text { safaris }\end{array}$ \\
\hline Kudu & $\begin{array}{l}\text { Highly preferred for subsistence and } \\
\text { safaris }\end{array}$ \\
\hline Zebra & Hunting and photographic safaris \\
\hline Waterbuck & $\begin{array}{l}\text { Hunting and photographic safaris. } \\
\text { Rarely poached }\end{array}$ \\
\hline Bushbuck & Highly preferred for meat \\
\hline Warthog & Highly preferred for meat \\
\hline Bushpig & Highly preferred for meat \\
\hline Duiker & Preferred for meat \\
\hline Impala & Highly preferred for meat \\
\hline Steenbuck & Poached for meat \\
\hline Baboon & $\begin{array}{l}\text { Not preferred for meat but body } \\
\text { parts used for traditional medicine }\end{array}$ \\
\hline Jackal & $\begin{array}{l}\text { Not preferred for meat, but parts of } \\
\text { body used for traditional medicine }\end{array}$ \\
\hline Reedbuck & Poached for meat \\
\hline Monkey & Not preferred for subsistence \\
\hline $\begin{array}{l}\text { A variety of bird spe- } \\
\text { cies }\end{array}$ & Harvested for subsistence \\
\hline $\begin{array}{l}\text { A variety of rodent } \\
\text { species }\end{array}$ & Harvested for subsistence \\
\hline A variety of insects & Harvested for subsistence \\
\hline $\begin{array}{l}\text { A variety of caterpil- } \\
\text { lars }\end{array}$ & $\begin{array}{l}\text { Mopane worm harvested for both } \\
\text { subsistence and commercialisation }\end{array}$ \\
\hline
\end{tabular}

\section{Conclusion}

Forest resources are important to livelihoods and well-being of people surrounding forests and that there is a strong differentiation in resource use amongst households and that there is also a wide range of products that are extracted. The types of resources used and the degree of use vary between 
households. The management of protected forest reserves must contribute to the development of the surrounding communities if the management goals are going to be realised. The surrounding communities should be considered as important stakeholders with vested interest in protected forest reserves. The long-term survival of the forests hinges on direct benefits to the local population and steady increase in the locals' standard of living.

\section{References}

Anderson, I.P., Brinn, P.J., Moyo, M., Nyamwanza, B., 1993. Physical resource inventory of the communal lands of Zimbabwe-an overview. NRI Bulletin 60, Natural Resources Institute, Chatham, UK.

Arnold, J.E.M., 1998. Forestry and sustainable rural livelihoods. In: Carney, D. (Ed.), Sustainable Rural Livelihoods; What contribution can we make, DFID, London, UK.

Bradley, P.N., Dewees, P.A., 1993. Indigenous woodlands, agricultural production and household economy in communal areas. In: Bradley, P.N., McNamara, K. (Eds.), Living with trees: policies for forestry management in Zimbabwe. World Bank Technical Paper 210, World Bank, Washington DC, 63-157.

Brigham, T., Chihongo, A., Chidumayo, E., 1996. Trade in woodland products from the miombo region. In: Campbell, B. (Ed.) The miombo in transition: Woodlands and welfare in Africa. CIFOR, Bogor, Indonesia.

Brummitt, R.K., 1986. A taxonomic perspective of the genus Baikiaea. In: Piearce, G.D. (Ed.), The Zambezi Teak Forests. Proceedings of the first international conference on the teak forests of southern Africa. Livingstone, Zambia, March 1984, 61-73.

Burger, W.K., 1993. Enumeration and management of the indigenous woodlands of northern Botswana. In: Piearce, G.D., Gumbo, D.J. (Eds.), The ecology and management of indigenous forests in Southern Africa. Proceedings of an international symposium, Victoria Falls, Zimbabwe, 27-29 July, 1992. Forestry Commission, Zimbabwe, 43-54.

Campbell, B.M., 1987. The use of wild fruits in Zimbabwe. Economic Botany 41, 375-385.

Campbell, B.M., Vermeulen, S.J., Lynam, T.J.P., 1991. Value of trees in the small-scale farming sector of Zimbabwe. International Development Research Centre, Ottawa. Canada. 72.

Campbell, B.M., Lucket, M., Scoones, I., 1997. Local-level valuation of savanna resources: a case study from Zimbabwe. Economic Botany 51, 59-77.

Campbell, B.M., Swift, M.J., Hatton, J., Frost, P.G.H., 1988. Small-scale vegetation pattern and nutrient cycling in Miombo woodland. In: Verhoeven, J.T.A., Heil, G.W., Werger, M.J.A. (Eds.), Vegetation structure in relation to carbon and nutrient economy. SPB Academic Publishing, The Hague, 69-85.
Cavendish, W.P., 1996. Environmental resources and rural household welfare. Mimeo, Centre for the Study of African Economics, University of Oxford.

Chambers, R., 1992. Rural Appraisal: rapid, relaxed and participatory. IDS Discussion Paper 311, Sussex.

Chambers, R., 1994a. The origins and practice of Participatory Rural Appraisal. World Development 22(7), 953-969.

Chambers, R., 1994b. PRA: Challenges, potentials and paradigms. World Development 22(10), 1437-1454.

Chambers, R., 1997. Relaxed and participatory appraisal: Notes on practical approaches and methods. Institute of Development Studies, University of Sussex, Brighton, England.

Childes, S.L., Walker, B.H., 1987. Ecology and dynamics of the woody vegetation on the Kalahari Sands in Hwange National Park, Zimbabwe. Vegetatio 72, 111-128.

Clarke, J., Cavendish, W., Coote, C., 1996. Rural household and miombo woodlands. Use, value and management. In: Campbell, B. (Ed.), The miombo in transition: woodlands and welfare in Africa. CIFOR, Bogor, Indonesia, 300-324.

Clay, J.W., 1997. The impact of palm heart harvesting in the Amazon estuary. In: Freese, C.H. (Ed.), Harvesting Wild Species: Implications for Biodiversity Conservation, John Hopkins University Press, Baltimore, MD, 283-314.

Cunliffe, R.N., 2000. Environmental assessment of current land use and four settlement options for Gwaai and Bembesi state forests. Shared Forest Management Preparation Project Report. Forestry Commission/DFID, Harare.

Cunningham, A.B., 1993. African Medicinal Plants. Setting Priorities at the Interface between Conservation and Primary Healthcare. People and Plant Working Paper 1, UNESCO, Paris, France.

Denevan, W.M., 1992. The pristine myth: The landscape of the Americas in 1492. Annals of the Association of American Geographers 82, 369-385.

Dewees, P.A., 1994. Social and economic aspects of miombo woodland management in Southern Africa. Options and opportunities for research. CIFOR Occassional Paper 2, Bogor, Indonesia.

Falconer, J., 1990. The major significance of 'Minor' forest products: The local use and value of forests in the West African humid forest zone. Community Forestry Note 6 , Rome, FAO.

Fanshawe, D.B., Savory, B.M., 1964. Baikiaea plurijuga dwarf shelf forests. Kirkia 4, 185-190.

Forestry Commission, 1992. Fuller Forest Management Plan. Forestry Commission. Bulawayo.

Forestry Commission, 1994. Community based natural resources management project. Pilot forest grazing and wildlife management programme in Mafungabusi Forest. Preliminary results of the feasibility study. Forest Extension Services Division, Forestry Commission. Harare.

Fortmann, L., Nabane, N., 1992. Fruits of their labours: 
gender, property and trees in Mhondoro District. NRM Occasional Paper 7, Center for Applied Sciences, University of Zimbabwe.

Huckabay, J.D., 1986. The geography of Zambezi teak. In: Piearce, G.D. (Ed.), The Zambezi Teak Forests. Proceedings of the first international conference on the teak forests of southern Africa. Livingstone, Zambia, March 1984, 5-23.

Judge, J.G., 1975. The Kalahari Sand Forests of Rhodesia: Management Report.

Kuipers, S.E., 1997. Trade in medicinal plants. In: Bodeker, G., Bhat, K.K.S., Burley, J., Vantomme, P. (Eds.), Medicinal Plants for Forest Conservation and Health Care, Food and Agriculture Organization, Rome, Italy, 45-59.

Kumar, K., 1993. Rapid appraisal methods. World Bank, Washington D.C.

Lockett, N., 1979. The geology of the country around Dett. Bulletin of Geological Survey, Rhodesia, 85.

Mangoyana R.B., Mujuru, F., Sola, P., 2003. An Overview Assessment of Indigenous Fruit Trees Based Products Commercialisation Feasibility In Gokwe South And Hurungwe, BMZ and SAFIRE Working Paper, SAFIRE.

McGregor, J., 1991. Woodland resources: ecology, policy and ideology. A historical case study of woodland use in Shurugwi communal area, Zimbabwe. Ph.D. thesis, Loughborough University of Technology, Loughborough.

McGregor, J., 1995. Gathered produce in Zimbabwe's communal areas: changing resource availability and use. Ecology of food and nutrition 33, 163-193.

Mudekwe, J., 2002. Adaptive co-management project: Mafungabusi forest reserve: Baseline study of the forest resources and collaborative monitoring mechanisms guidelines. Unpublished report. Forest Research Centre, Forestry Commission, Harare.

Mukamuri, B.B., 1995. Local environment conservation strategies: Karanga religion, politics and environmental control. Environment and History 1, 297-311.

Nepstad, D.C., Schwartzman, S., 1992. Non-timber forest products from tropical forests: Evaluation of a conservation and development strategy. New York: New York Botanical Gardens.

Nyamapfene, K., 1991. The soils of Zimbabwe. Nehanda Publishers, Harare.

Peters C.M., 1996. Observations on the sustainable exploitation of non-timber forest products. An Ecologist's Perspective. In: Ruiz Perez, M., Arnold, J.E.M. (Eds.), Current issues in non-timber forest products research. Proceedings of the workshop 'Research on NTFP' Hot Springs, Zimbabwe $28^{\text {th }}$ August-2 September 1995, 68-73.

Plan Afric, 2002. Shared Forest Management Preparation
Project. Institutions around forests. Forestry Commission, Bulawayo.

Posey, D., 1982. Keepers of the forest. Garden 6, 18-24.

Rebelo, A.G., Holmes, P.M., 1988. Commercial exploitation of Brunia albiflora (Bruniaceae). South African Journal of Botany 45, 195-207.

Shackleton, C.M., Dzerefos, C.M., Shackleton, S.E., Mathebela, F.R., 2000a. The use and trade in indigenous edible fruits in the Bushbuckridge savanna region, South Africa. Ecology of Food and Nutrition 39, 225-245.

Shackleton, S., Shackleton, C., Netshiluvi, T., Geach, B., Balance, A., 2000b. How valuable are our woodlands for sustainable rural livelihoods? Local-level valuation of woodland resources from three villages in South Africa. In: Seydack, A.H.W., Vermeulen, W.J., Vermeulen, C. (Eds.), Towards sustainable management based on scientific understanding of natural forests and woodlands. Proceedings of a Natural Forests and Savanna Woodlands Symposium II Knysna, South Africa, 5-9 September 1999, 305-321.

Shackleton. C.M., Netshiluvhi, T.R., Shackleton, S.E., Geach, B.S., Balance, A., Fairbanks, D.F., 1999. Direct use values of woodland resources from three rural villages. Unpublished report ENV-P-I 98210, CSIR, Pretoria, 221.

Ticktin, T., 2004. The ecological implications of harvesting non-timber forest products. Journal of Applied Ecology $41,11-21$.

Timmermans, H., 2000. Reconciling conservation and rural development: Social and ecological dynamics of forest resource harvesting in the Cwebe Nature Reserve. In: Seydack, A.H.W., Vermeulen, W.J. and Vermeulen, C. (Eds). Towards sustainable management based on scientific understanding of natural forests and woodlands. Proceedings of a Natural Forests and Savanna Woodlands Symposium II Knysna, South Africa, 5-9 September 1999, 332-341.

Tiwari, B.K., 2000. Non-timber forest produce of north east India. Journal of Human Ecology 11, 445-455.

Vermeulen, S., 1993. Consumption, harvesting and abundance of wood along the boundary between Mafungautsi State Forest and Gokwe Communal Area, Zimbabwe. M.Sc thesis, University of Zimbabwe, Harare.

Wilson, K.B., 1989. Trees in fields in Southern Zimbabwe. Journal of Southern African Studies 15, 369-383.

Wood. A.P., 1986. Man's impact upon the mukusi forests of Zambia, with special reference to Sesheke District. In: Piearce, G.D. (Ed.), The Zambezi Teak Forests. Proceedings of the first international conference on the teak forests of southern Africa. Livingstone, Zambia, March 1984, 24-42. 